\title{
Pemberdayaan Petani Hortikultura (Kasus Kelompok Tani Werdhi Guna Desa Pempatan, Kecamatan Rendang, Kabupaten Karangasem)
}

\author{
I KOMANG JUNIARTA, I MADE SARJANA, \\ NYOMAN PARINING \\ Program Studi Agribisnis, Fakultas Pertanian, Universitas Udayana \\ J1. PB. Sudirman Denpasar 80323, Bali \\ Email: komang_juniarta66@yahoo.com \\ sarjanasosek@yahoo.com
}

\begin{abstract}
Empowerment of Horticultural Farmers: The Case of Werdhi Guna Farmer Group of Pempatan Village, Rendang District, Karangasem Regency
\end{abstract}

Pempatan Village, Rendang District, Karangasem Regency has great vegetable potential, but farmers have not been able to utilize the condition well. There needs to be empowerment to increase farmer's income and farmer's prosperity. The purpose of this research is to know (1) horticultural potential (2) process of empowering horticulture farmers. This research used qualitative and quantitative analysis methods. The results showed the potential of vegetable horticulture (Olericulture) in Werdhi Guna Farmer Group with the achievement of score 4.2 with the good category meaning that Werdhi Guna Farmer Group has a tropical area and is suitable for horticultural cultivation. Horticultural plants grow with maximum results, seen from the fact that vegetable crops are fertile although obstacles still persist such as the limited availability of water for watering plants. As for the empowerment of farmers, it is of good category with average achievement score of 3.9 meaning that the farmers play an important role in horticultural cultivation and the importance of government roles given to Werdhi Guna Farmer Group in enhancing knowledge or innovation in agriculture. In this research, it is suggested that farmers in Werdhi Guna Farmer Group are expected to be able to increase their horticultural products in order to be able to compete in the market to improve farmer's welfare, and of course to promote vegetable farming (Olericulture) and the government should pay more attention to horticultural farmers and provide support in the form of aid and training that can make them able to increase their farming.

Keywords: farmer group, potential, empowerment, horticultural farmers

\section{Pendahuluan}

\subsection{Latar Belakang}

Pemberdayaan masyarakat adalah suatu proses yang mengembangkan dan memperkuat kemampuan masyarakat untuk terus terlibat dalam proses pembangunan yang berlangsung secara dinamis sehingga masyarakat dapat menyelesaikan masalah 
yang dihadapi serta dapat mengambil keputusan secara bebas dan mandiri (Suharto 2005).

Pemberdayaan masyarakat menyiratkan perbaikan, pertumbuhan, perubahan, dan pembangunan. Dibutuhkan kerjasama dari seluruh lapisan masyarakat untuk memulai, melaksanakan, dan mempertahankan upaya untuk memperbaiki situasi mereka. Pengembangan masyarakat memang bertujuan untuk membantu orang memperbaiki keadaan sosial dan ekonominya, namun bukan berarti bahwa masyarakat hanya bertindak sebagai obyek yang menerima, melainkan mereka juga harus bertindak sebagai subyek yang bertindak dan berusaha untuk memperoleh kesejahteraan itu sendiri. Jumlah penduduk miskin di Bali salah satunya di Kabupaten Karangasem jumlah penduduk miskin adalah 29,7 ribu orang (7,30 persen) dari jumlah semua penduduk di Karangasem (BPS Provinsi Bali, 2015). Daerah miskin tersebut menyebar diseluruh wilayah Karangasem dari dusun-dusun di dataran tinggi, masyarakat tepian hutan, desa-desa kecil yang miskin, masyarakat petani ataupun daerah-daerah kumuh di perkotaan. Misalnya di Desa Pempatan Kecamatan Rendang mayoritas masyarakat adalah petani hortikultura.

Kelompok tani merupakan kelembagaan di tingkat petani yang dibentuk untuk secara langsung mengorganisasi para petani dalam berusahatani. Kementerian pertanian mendefinisikan kelompok tani sebagai kumpulan petani/peternak/pekebun yang dibentuk atas dasar kesamaan kepentingan, kesamaan kondisi lingkungan dan keakraban untuk meningkatkan dan mngembangkan usaha anggota. Kelompok tani dibentuk oleh dan untuk petani guna untuk mengatasi masalah bersama dalam usahatani serta menguatkan tawar petani, baik dalam pasar maupun pasar produk pertanian (Hermanto 2011).

Hortikultura merupakan pertanian khas tropis yang potensial untuk dikembangkan di Desa Pempatan sebagian besar yaitu tanaman hortikultura sayur-sayuran (Olerikultura) salah satu sub sektor dalam sektor pertanian yang berpotensi untuk dikembangkan karena memiliki nilai ekonomis yang cukup tinggi di pasaran domestik maupuan pasar internasional. Salah satunya adalah Kelompok Tani Wardhi Guna yang telah lama berbudidaya tanaman hortikultura sayur-sayuran (Olerikultura). Kelompok Tani Wardhi Guna di Desa Pempatan merupakan salah satu kelompok tani yang mengembangkan hortikultura sayur-sayuran (Olerikultura) seperti jenis tamanan sayuran tomat, cabe besar, cabe kecil, kacang buncis, kubis, sawi, timun, dan terong. Jenis sayur-sayuran ini merupakan kebutuhkan sehari-hari oleh konsumen dan permintaannya cenderung terus meningkat di pasaran.

Pertumbuhan tanaman sayuran menunjukan bahwa terjadinya penurunan dan peningkatan produksi tanaman sayuran di Kelompok Tani Wardhi Guna Desa Pempatan. Terdapat beberapa jenis sayuran mengalami peningkatan produksi, tetapi ada pula sayuran yang mengalami penurunan produksi setiap tahunnya. Salah satu contoh jenis hortikultura yang mengalami penurunan produksi yaitu tanaman sayuran kubis di Desa Pempatan selama kurun waktu tiga tahun terakhir yaitu pada tahun 2014-2016. Luas lahan tanaman hortikultura kubis pada tahun 2014 seluas 148 hektar dengan produksi sebanyak 29.521,6 ton, mengalami penurunan pada tahun 2015 seluas 97 hektar dengan penurunan produksi 17.382,4 ton. Pada tahun 2016 mengalami penurunan dengan luas lahan sebesar 32 hektar dengan jumlah produksi sebanyak $5.734,4$ ton. Hal ini dikarenakan harga selalu mengalami perubahan, alam dan finansial pada tanaman hortikultura kubis. (Monografi Desa Pempatan Karangasem) 
Jenis hortikultura yang mengalami peningkatan produksinya yaitu tanaman cabe besar di Desa Pempatan selama kurun waktu tiga tahun terakhir yaitu pada tahun 20142016. Lahan tanaman hortikultura cabe pada tahun 2014 seluas 89 Hektar dengan memproduksi buah sebanyak 15.479,5 ton, mengalami peningkatan pada tahun 2015 sebesar 134 hektar dengan produksi sebanyak 27.567,4 ton. Pada tahun 2016 tanaman cabe mengalami peningkatan dengan luas lahan sebesar 153 hektar dan tingkat produksi 32.674,6 ton dikaranakan hatga jual lebih tinggi selain itu cabe merupakan kebutuhan sehari-hari. (Monografi Desa Pempatan Karangasem)

\subsection{Rumusan Masalah}

Berdasarkan uraian dengan latar belakang yang telah diuraikan, maka yang menjadi rumusan masalah dalam penelitian ini adalah sebagai berikut:

1. Bagaimana potensi hortikultura sayur-sayuran (Olerikultura) di kelompok Tani Wardhi Guna Desa Pempatan?

2. Bagaimana proses pemberdayaan petani hortikultura sayur-sayuran (Olerikultura) Tani Wardhi Guna Desa Pempatan ?

\subsection{Tujuan Penelitian}

Berdasarkan rumusan masalah diatas, maka tujuan dari penelitian ini adalah sebagai berikut.

1. Untuk mengetahui potensi hortikultura sayur-sayuran (Olerikultura) yang ada di kelompok Tani Wardhi Guna Desa Pempatan.

2. Untuk mengetahui pemberdayaan petani hortikultura sayur-sayuran (Olerikultura) di kelompok Tani Wardhi Guna Desa Pempatan.

\section{Metode Penelitian}

\subsection{Lokasi dan Waktu Penelitian}

Lokasi penelitian ini bertempat di Kelompok Tani Werdhi Guna Desa Pempatan, Kecamatan Rendang, Kabupaten Karangasem. Pemilihan lokasi penelitian ini dengan metoda purposife, yaitu metoda penentuan lokasi yang dilakukan secara sengaja dan pertimbangan. Waktu pengumpulan data untuk menunjang usulan proposal dilakukan pada bulan Juni s/d Agustus 2017, yaitu terhitung dari proses pengumpulan data penulisan.

\subsection{Jenis dan Sumber Data}

Jenis data yang digunakan dalam penelitian ini adalah data kualitatif dan data kuantitatif. Data kualitatif meliputi hasil pengamatan langsung di lapangan berupa gambaran umum lokasi penelitian, hasil dari wawancara, informasi yang berkaitan dengan tanaman hortikultura sayur-sayuran (olerikultura). Data kuantitatif meliputi jumlah populasi anggota kelompok, jumlah sampel, umur responden, pendidikan responden, dan luas lahan di Kelompok Tani Werdhi Guna di Desa Pempatan.

Sumber data yang digunakan dalam penelitian ini adalah data primer dan data sekunder. Data primer merupakan data yang diperoleh secara langsung dari sumbernya yaitu melalui wawancara dan pengisian daftar pertanyaan (kuesioner) kepada para responden (Sugiyono, 2011). Data primer yang diperlukan dalam penelitian ini adalah 
karakteristik responden yang meliputi nama, jenis kelamin, tingkat pendidikan, pekerjaan sampingan, dan luas lahan garapan. Data sekunder merupakan data yang berupa dokumen-dokumen yang diperoleh secara tidak langsung. Data sekunder dalam penelitian ini meliputi, artikel, literatur, jurnal, internet, dan dokumen kelompok tani. Data sekunder yang diperoleh melalui pencatatan langsung seperti profil kelompok tani, keadaan geografis, struktur organisasi, dan jumlah anggota Kelompok.

\subsection{Teknik Pengumpulan Data}

Metode yang digunakan oleh peneliti untuk mengumpulkan data sebagai berikut. Wawancara (interview) adalah teknik pengumpulan data dengan melakukan tanya jawab kepada responden yaitu kepada anggota Kelompok Tani Werdhi Guna, wawancara mendalam (indepth interview) merupakan proses memperoleh keterangan untuk tujuan penelitian dengan cara tanya jawab dan tatap muka kepada ketua kelompok tani, observasi merupakan teknik pengumpulan data yang dilakukan dengan pengamatan secara langsung pada objek penelitian yakni pengamatan langsung pada daerah penelitian yaitu Kelompok Tani Werdhi Guna, dokumen biasanya berbentuk tulisan, gambar, atau karya-karya monumental dari seseorang.

\subsection{Instrumen Penelitian}

Instrumen penelitian merupakan suatu alat yang dapat digunakan oleh peneliti untuk mengumpulkan data dan dapat mempermudah pekerjaan dengan hasil yang lebih baik. Instrumen penelitian juga dapat membantu peneliti untuk mendapatkan data secara lebih cermat, lengkap dan sistematis, sehingga dapat lebih mudah untuk diolah (Arikunto, 2012).

Instrumen pengumpulan data penelitian ini menggunakan daftar pertanyaan (kuesioner) dan alat potret (kamera) untuk mendokumentasikan kegiatan atau kondisi lapangan. Kuesioner merupakan merupakan instrument pegumpulan data yang berisikan pernyataan terstruktur tertulis yang digunakan untuk memproleh informasi dari responden. Instrumen penelitian pada umumnya perlu mempunyai dua syarat penting yaitu valid dan reliabel (Sukardi, 2003). Kuesioner digunakan untuk mendapat informasi dari responden maka perlu terlebih dahulu dilakukan uji kesahihan dan keterandalan.

\subsection{Populasi dan Responden}

Menurut Sugiyono (2010), populasi adalah wilayah generalisasi yang terdiri atas objek/subjek yang mempunyai kualitas dan karakteristik tertentu yang ditetapkan oleh penelitian untuk dipelajari dan kemudian ditarik kesimpulan. Berdasarkan definisi di atas, populasi merupakan objek atau subjek yang berada pada suatu wilayah dan memenuhi syarat tertentu yang berkaitan dengan masalah penelitian. Populasi dalam penelitian ini adalah semua anggota Kelompok Tani Werdhi Guna. Sampel adalah sebagian dari jumlah dan karakteristik yang dimiliki oleh populasi tersebut. Metode yang digunakan adalah teknik sensus seluruh populasi dijadikan responden dalam penelitian ini, jumlah responden penelitian ini sebanyak 20 orang. 


\subsection{Analisis Data}

Menurut Sugiyono (2009), analisis data adalah proses mencari dan menyusun data yang diperoleh dari hasil wawancara, catatan lapangan, dan bahan-bahan lain secara sistematis sehingga mudah dipahami dan temuannya dapat diinformasikan kepada orang lain. Penelitian ini digunakan analisis data deskriptif kualitatif. Data yang diperoleh selanjutnya diolah dan ditabulasikan dalam bentuk tabel dan dihitung frekuensi serta persentasenya dengan bantuan skoring mengunakan skala ordinal (berjenjang lima).

\section{Hasil dan Pembahasaan}

\subsection{Potensi}

Potensi merupakan suatu kemampuan, kesanggupan, kekuatan ataupun daya yang mempunyai kemungkinan untuk bisa dikembangkan atau diberdayakan menjadi bentuk yang lebih besar (Madji, 2007). Kelompok Tani Werdhi Guna mengembangkan hortikultra sayur-sayuran (Olerikultura) seperti jenis tanaman sayuran tomat, cabe besar, cabe kecil, kacang buncis, kubis, sawi, timun, dan terong, untuk tanaman sayuran yang ditanam pada saat penelitian di Kelompok Tani Werdhi Guna adalah tomat dan cabe besar di karenakan harga jual lebih tinggi selain itu cabe merupakan kebutuhan seharihari. Pencapaian skor pada potensi Kelompok Tani Werdhi Guna diukur melalui tiga indikator yaitu sumber daya alam (SDA), sumber daya manusia (SDM), dan sumber daya finansial (SDF).

\subsubsection{Sumber Daya Alam}

Sumber daya alam (SDA) adalah sesuatu yang berasal dari alam yang bisa dimanfaatkan untuk berbagai kebutuhan hidup manusia dan dapat memberikan keuntungan bagi manusia pencapain skor sumber daya alam yang dimaksud dalam penelitian ini adalah skor penilaian responden terhadap sumber daya alam di Kelompok Tani Werdhi Guna yang terdiri dari tanah, air dan iklim. Pencapaian skor berdasarkan sumber daya alam di Kelompok Tani Werdhi Guna dapat dilihat pada Tabel 1.

Tabel 1.

Pencapaian Skor Berdasarkan Sumber Daya Alam di Kelompok Tani Werdhi Guna

\begin{tabular}{|c|c|c|c|}
\hline No & Parameter & Pencapaian Skor & Kategori \\
\hline 1 & Tanah & 4,7 & Sangat baik \\
\hline 2 & Air & 3,8 & Baik \\
\hline 3 & Iklim & 4,7 & Sangat baik \\
\hline & Sumber Daya Alam & 4,4 & Sangat baik \\
\hline
\end{tabular}

Hasil penelitian ini menunjukan bahwa sumber daya alam di Kelompok Tani Werdhi Guna termasuk dalam katagori sangat baik dengan total skor yaitu 4,4. Artinya sumber daya alam di Kelompok Tani Werdhi Guna cocok untuk ditanamani tanaman hortikultural. Kesuburan tanah dan iklim yang cocok untuk tanaman sayur-sayuran dengan hasil yang maksimal dilihat dari perkembangan tanaman sayuran yang subur dan hasil buah yang lebat sehingga mengasilkan produsi yang tinggi. Sumber daya alam terdiri dari tiga parameter; parameter tanah dengan pencapaian skor sebesar 4,2 berada pada katagori sangat baik, parameter air dengan pencapaian skor sebesar 3,8 berada 
pada katagori baik, parameter iklim dengan pencapain skor sebesar 4,7 berada pada katagori sangat baik.

\subsubsection{Sumber Daya Manusia}

Sumber daya manusia (SDM) adalah potensi yang dimiliki oleh anggota kelompok tani dan penyulih yang dikembangkan menjadi suatu kekuatan. Pencapain skor sumber daya manusia yang dimaksud dalam penelitian ini adalah skor penilaian responden terhadap sumber daya manusia di Kelompok Tani Werdhi Guna yang terdiri dari petani dan penyuluh. Pencapaian skor berdasarkan sumber daya manusia di Kelompok Tani Werdhi Guna dapat dilihat pada Tabel 2.

Tabel 2.

Pencapaian Skor Berdasarkan Sumber Daya Manusia di Kelompok Tani Werdhi Guna

\begin{tabular}{clcc}
\hline No & Parameter & Pencapaian skor & Kategori \\
\hline 1 & Petani & 3,8 & Baik \\
2 & Penyuluh & 4,4 & Sangat baik \\
\hline & Sumber Daya Manusia & 4,1 & Baik \\
\hline
\end{tabular}

Hasil penelitian ini menunjukan bahwa sumber daya manusia (SDM) di Kelompok Tani Werdhi Guna termasuk dalam katagori baik dengan total skor yaitu 4,1. Artinya sumber daya manusia di Kelompok Tani Werdhi Guna menunjukan bahwa petani berperan penting dalam budidaya tanaman hortikultural dan PPL (Penyuluh Pertanian Lapangan) memberikan inovasi seperti materi teknologi pengendalian hama terpadu (PTH) dapat memberikan pengetahuan tentang pengendalian hama untuk meningkatkan produksi hortikultura. Sumber daya manusia terdiri dari dua parameter; parameter petani pencapaian skor 3,8 dikategorikan baik, pada parameter penyuluh dengan pencapaian skor sebesar 4,4 dan dikategorikan sangat baik.

\subsubsection{Sumber Daya Finansoal}

Sumber daya finansial (SDF) adalah kemampuan yang dimiliki oleh Kelompok Tani Werdhi Guna yang meliputi modal finansial (uang, pupuk, bibit, dan obat-obatan) dan alat finansial (alat mesin pertanian) yang ada di dalam Kelompok Tani Werdhi Guna. Yang dimaksud dalam penelitian ini adalah skor penilaian responden terhadap sumber daya finansial di Kelompok Tani Werdhi Guna yang terdiri dari Modal Financial dan alat finansial. Pencapaian skor berdasarkan sumber daya financial di Kelompok Tani Werdhi Guna dapat dilihat pada Tabel 3.

Tabel 3.

Pencapaian Skor Berdasarkan Sumber Daya Financial di Kelompok Tani Werdhi Guna

\begin{tabular}{clcc}
\hline No & \multicolumn{1}{c}{ Parameter } & Pencapaian skor & Kategori \\
\hline 1 & Modal financial & 4,1 & Baik \\
2 & Alat financial & 4,3 & Sangat Baik \\
\hline & Sumber Daya Manusia & 4,2 & Baik \\
\hline
\end{tabular}


Hasil penelitian ini menunjukan bahwa sumber daya finansial di Kelompok Tani Werdhi Guna termasuk dalam katagori baik dengan total skor yaitu 4,2. Artinya sumber daya financial di Kelompok Tani Werdhi Guna menunjukan bahwa petani cendrung menggunakan modal sendiri dalam berusaha tani. Modal yang dimaksud dalam penelitian ini adalah untuk pemeliharaan, pupuk, dan obat-obatan sedangkan pengunaan alat pertanian berupa sabit, cangkul, garu, spayer dan traktor sangat membantu petani dalam budidaya tanaman hortikultura. Sumber daya finansial terdiri dari dua parameter; parameter modal finansial pencapaian skor sebesar 4,1 dengan kategori baik, parameter alat financial dengan pencapaian skor sebesar 4,3 dan dikategorikan sangat baik.

\subsection{Pemberdayaan Petani Hortikultural Pada Kelompok Tani Werdhi Guna}

Schuler, Hashemi \& Riley (dalam Suharto, 2005) mengembangkan indikator keberdayaan yang disebut indeks pemberdayaan (empowermant index). Keberasilan pemberdayaan masyarakat dapat dilihat dari keberdayaan mereka yang menyangkut kemampuan ekonomi, kemampuan mengakses manfaat kesejahteraan, kemampuan kultural dan politis. Ketiga aspek tersebut dikaitkan dengan emapat dimensi kekuasaan, yaitu kekuasaan di dalam (power within), kekuasaan untuk ( power to), kekuasaan atas (power over) dan kekuasaan dengan (pawer with).

Sebelum mengetahui fokus dan tujuan pemberdayaan secara operasional, maka perlu diketahui berbagai indikator keberdayaan yang dapat menunjukkan seseorang itu berdaya atau tidak. Sehingga ketika sebuah program pemberdayaan diberikan, segenap upaya dapat dikonsentrasikan pada aspek-aspek apa saja dari sasaran perubahan (misalnya keluarga miskin) yang perlu dioptimalkan. Keberhasilan pemberdayaan masyarakat dapat dilihat dari keberdayaan mereka menyangkut kemampuan ekonomi, kemampuan mengakses manfaat kesejahteraan, dan kemampuan kultural dan politis.

\subsubsection{Kemampuan ekonomi}

Kemampuan ekonomi merupakan kemampuan Kelompok Tani Werdhi Guna untuk mencangkup produksi, daya saing dan pemasaran yang dapat memenuhi kebutuhan hidup petani dan meningkatkan kesejahteraan petani di Kelompok Tani Werdhi Guna. Kelompok Tani Werdhi Guna yang terdiri dari produksi, pemasaran dan daya saing. Pencapaian skor berdasarkan kemampuan ekonomi di kelompok tani Werdhi Guna dapat dilihat pada Tabel 4.

Tabel 4.

Pencapaian Skor Berdasarkan Kemampuan Ekonomi di Kelompok Tani Werdhi Guna

\begin{tabular}{|c|c|c|c|}
\hline No & Indikator & $\begin{array}{c}\text { Pencapaian } \\
\text { Skor }\end{array}$ & Katagori \\
\hline 1 & Produksi & 3,6 & Baik \\
\hline 2 & Pemasaran & 3,4 & Sedang \\
\hline 3 & Daya Saing & 3,3 & Sedang \\
\hline & Kemapuan Ekonomi & 3,4 & Sedang \\
\hline
\end{tabular}

Hasil penelitian ini menunjukan bahwa kemampuan ekonomi di Kelompok Tani Werdhi Guna termasuk dalam katagori sedang dengan total skor yaitu 3,4. Artinya kemampuan ekonomi di Kelompok Tani Werdhi Guna masih belum mampu 
memasarkan hasil produksi hortikultura. Petani masih memasarkan hasil produksi di pasar lokal dan ke tengkulak, banyaknya produksi tanaman hortikulutra dari daerah lain yang mengakibatkan saingan produksi hortikulturan dalam pemasaran produksi. Kemampuan ekonomi terdiri dari tiga parameter; parameter produksi pencapaian skor sebesar 3,6 dengan kategori baik, parameter pemasaran dengan skor 3,4 berada pada kategori sedang, parameter daya saing dengan skor 3,3 berada di kategori sedang.

\subsubsection{Kemampuan mengakses kesejahteraan}

Kemampuan mengakses kesejahteraan merupakan kemampuan Kelompok Tani Werdhi Guna dalam pengetahuan, pelatihan dan ketrampilan dalam berbudidaya tanaman hortikultural yang lebih baik. Pencapaian skor berdasarkan kemampuan mengakses kesejahteraan di Kelompok Tani Werdhi Guna dapat dilihat pada Tabel 5.

Tabel 5.

Pencapaian Skor Berdasarkan Kemampuan Mengakses Kesejahtraan di Kelompok Tani Werdhi Guna

\begin{tabular}{clcc}
\hline No & Indikator & $\begin{array}{c}\text { Pencapaian } \\
\text { Skor }\end{array}$ & Katagori \\
\hline 1 & Pengetahuan & 4,3 & Sangat Baik \\
2 & Ketrampilan & 4,1 & Baik \\
3 & Pelatihan & 4,2 & Baik \\
\hline & Kemampuan Mengakses Kesejahtraan & 4,2 & Baik \\
\hline
\end{tabular}

Hasil penelitian ini menunjukan bahwa kemampuan mengakses kesejahtraan di Kelompok Tani Werdhi Guna termasuk dalam katagori baik dengan total skor yaitu 4,2. Artinya kemampuan mengakses kesejahtraan di Kelompok Tani Werdhi Guna petani sudah mampu memahami inovasi yang diberikan oleh PPL (Penyuluh Pertanian Lapangan) seperti memberikan SL-PHT (Sekolah Lapangan Pengendalian Hama Terpadu) dan petani memiliki keterampilan dalam mengelola tanaman dari pengelola lahan sampai pasca panen untuk meningkatkan produksi tanaman hortikultura. Kemampuan mengakses kesejahtraan terdiri dari tiga parameter; parameter pengetahuan pencapaian skor sebesar 4,3 dengan kategori sangat baik, parameter keterampilan dengan skor 4,1 berada pada kategori baik, parameter pelatihan dengan skor 4,2 berada pada kategori baik.

\subsubsection{Kemapuan kultur dan politis}

Kemampuan kultural dan politis merupakan lembaga pemerintah yang berperan penting memenuhi dan mendukung petani atau kelompok tani untuk memenuhi kebutuhannya dalam melakukan budidaya tanaman hortikultural agar kesejahteraan petani meningkat. Pencapaian skor berdasarkan kemampuan kultur dan politis di Kelompok Tani Werdhi Guna dapat dilihat pada Tabel 6. 
Tabel 6.

Pencapaian Skor Berdasarkan Kemampuan Kultural dan Politis di Kelompok Tani Werdhi Guna

\begin{tabular}{|c|c|c|c|}
\hline No & Indikator & $\begin{array}{l}\text { Pencapaian } \\
\text { Sekor }\end{array}$ & Katagori \\
\hline 1 & Partisipasi & 4,2 & Baik \\
\hline 2 & Kelompok & 4,2 & Baik \\
\hline 3 & Pemerintah & 4,2 & Baik \\
\hline & Kemampuan Kultural dan Politis & 4,2 & Baik \\
\hline
\end{tabular}

Hasil penelitian ini menunjukan bahwa kemampuan kultural dan politis di Kelompok Tani Werdhi Guna termasuk dalam katagori baik dengan total skor 4,2. Artinya kemampuan kultural dan politis di Kelompok Tani Werdi Guna sudah berjalan dengan baik. Keterlibatan petani dalam proses-proses budaya, koordinasi antara pengurus dengan anggota sudah berjalan dengan bagus. Adanya peranan pemerintah melalui inovasi baru yang disampaikan oleh penyuluh pertanian sehingga mampu meningkatkan kesejateraan petani. Kemampuan kultural dan politis terdiri dari tiga parameter; parameter partisipasi pencapaian skor sebesar 4,2 dengan kategori baik, parameter kelompok dengan skor 4,2 berada pada kategori baik, parameter pemerintah dengan skor 4,2 berada pada kategori baik.

\section{Kesimpulan dan Saran \\ 4.1 Kesimpulan}

Berdasarkan hasil penelitian dapat disimpulkan 1) Potensi Hortikultura di Kelompok Tani Werdhi Guna di Desa Pempatan untuk sumber daya alam tergolong kategori sangat baik, tamanan hortokulturan tumbuh dengan subur dan iklim yang ada di desa Pempatan sesuai untuk tanaman hortikultura. Sumber daya manusia tergolong kategori baik, petani di Kelompok Tani Werdi Guna memiliki kemampua dalam budidaya tanaman hortikultura. Sumber daya finansial tergolong baik petani menggunakan modal sendiri dalam berusaha tani. 2) Pemberdayaan petani hortikultura di Kelompok Tani Werdhi Guna di Desa Pempatan untuk Kemapuan ekonomi tergolong kategori sedang, petani di Kelompok Tani Werdhi Guna masih belum mampu memasarkan hasil produksi dengan maksimal. Kemapuan mengakses manfaat kesejahtraan tergolong kategori baik, petani di Kelompok Tani Werdhi Guna mampu meningkatkan produksi tanaman hortikultura. kempuan kultural dan politis tergolong kategori baik, pentingnya adanya peranan dari pemerintah di dalam Kelopok Tani Wedi Guna.

\subsection{Saran}

Berdasarkan pembahasan hasil penelitian dan kesimpulan maka dapat disarankan beberapa hal sebagai berikut. 1) Petani hortikultura di Kelompok Tani Werdhi Guna diharapkan mampu meningkatkan hasil produksi hortikutura agar mampu bersaing dipasar untuk meningkatkan kesejahtraan petani, dan tentunya dapat menajukan pertanian sayur-sayuran (Olerikutua). 2) Pemerintah lebih memperhatikan petani hortikultura dengan memberikan dukungan berupa bantuan pupuk bersubsidi, dana, dan alat pertanian di Kelompok Tani Werhi Guna. 3) PPL (penyuluh pertanian lapangan) bisa memberikan inovasi baru kepada petani hortikultura di Kelompok Tani Werdhi 
Guna untuk meningkatkan kualitas sayuran sehingga sayuran yang berkualitas tentunya akan meningkatkan harga tawar ketika menjualnya di pasaran.

\section{Ucapan Terimakasi}

Terimakasi kepada kepala Desa Pempatan, Kecamatan Rendang berserta jajaran atas izin yang telah diberikan kepada penulis, selanjutnya tidak lupa ucapan trimakasi kepada ketua Kelompok Tani Werdhi Guna Bapak I Wayan Arga Yasa berserta seluruh anggota kelompok tani yang telah meluangka waktu untuk penulis melakukan penelitian.

\section{Daftar Pustaka}

Arikunto, S. dkk. 2012. Penelitian Tindakan Kelas. Jakarta : Bumi Aksara.

BPS. 2015. Bali Berserta Kabupaten Dalam Angka 2014/2015. Kantor Statistik Bali.

Hermanto. 2011. Penguatan Kelompok Tani: Langkah Awal Peningkatan Kesejahteraan Petani, Bogor

Monografi Desa Pempatan Karangasem

Mudji. 2007. Pengertian Potensi. (Jurnal Online). http://pengertianmenurutparaahli.net/pengertian-potensi/. Diakses pada Tanggal 11 Februari 2017.

Sugiyono. 2009. Mengidentifikasi Potensi Budaya yang ada di Desa Sangsit Jagaraga dan Sawan Kecamatan Sawan Kabupaten Buleleng. \{Jurnal Online\}. Internet. http://www.pps.unud.ac.id/thesis/pdf_thesis/unud-251-1074479723-bab-iii.pdf.

Diakses pada tangal 26 November 2016.

Sugiyono. 2010 Statistik untuk Pendidikan. Bandung: Alfabeta.

Sugiyono. 2011. Metode Penelitian Kuantitatif Kualitatif dan R\&D. Bandung: Alfabeta

Suharto, Edi. 2005. Membangun Masyarakat, Memberdayaan Masyarakat: Kajian Stategis Pembangunan Kesejahteraan Sosial Dan Pekerjaan Sosial. PT. Rafika Aditama.Bandung.

Sukardi. 2003. Metodologi Penelitian Pendidikan. Jakarta:Bumi Aksara. 